\title{
Legal Pluralism Approach to Respond Challenge of Diversity and Religious Conflict Among Indonesian Society
}

\author{
Novita Dewi Masyithoh ${ }^{1}$, Suteki $^{2}$ \\ \{novita.dewi79@yahoo.co.id ${ }^{1}$, arjuna_teki@yahoo.com ${ }^{2}$ \} \\ ${ }^{1}$ Islamic State University of Walisongo, Jl. Walisongo No.3-5, Tambakaji, Ngaliyan, Kota Semarang, \\ Jawa Tengah 50185 \\ ${ }^{2}$ Diponegoro University, Jl.Prof. H. Soedarto, S.H. Tembalang, Tembalang, Kota Semarang, Jawa \\ Tengah, 50275, Indonesia
}

\begin{abstract}
Recently, Indonesia has been facing various problems of disharmony between religion and racial intolerance, which can arise disintegration of the nation and destruction of diversity in society. Some people consider themselves as the most "Pancasilaist" compared to the other groups, so that they attempt to dissolve specific religious organizations. Regarding this issue, the writer would investigate how the three discourses of moral-ethicreligion, state positivism, and socio-legal research of diversity and religiosity among the member of society are combined in order to reach religious harmony. This method used in this study to analyze the pluralism approach that combines three approaches, i.e., moral/ethic/religion, state positivism, and socio-legal approach. The result shows that there is an accumulation of violations of religious freedom and the strengthening of the issue of religious blasphemy. To solve these problems, the writer argues that support and participation of all elements of society are entirely required. Religious leaders and community leaders can use moral, ethical, and religious approaches to re-internalize the gracious values of religion and tolerance. Indeed, the non-penal policy becomes the foundation of life for the nation and state that must be continuously internalized. Whereas penal policy through law enforcement should prioritize unity; done in restorative and recitative justice; precede the ways of penal mediation, kinship, deliberation, and consensus. These should be applied to improve national unity and social order.
\end{abstract}

Keywords: Religious Conflict, Legal Pluralism, Diversity Issue, Restorative Justice, Indonesia

\section{Introduction}

Indonesia is an archipelago country with plural society from Sabang to Merauke. Tribes, religions, beliefs, languages, customs, and cultures have been unified in Indonesian nationhood with the slogan of Bhinneka Tunggal Ika. However, today, Indonesia has been facing some problems with diversity and religious issues. SARA abuse, radicalism, and terrorism have occurred and resulted in nation disunity. These problems arose mostly due to the disparity and disharmony in social, economic, and political life, which have considerably disregarded justice and prosperity for people.

In 2016, the issue of hate speech delivered by the former governor of DKI Jakarta, Ahok, has raised and sharpened because he misquoted Surat Al-Maidah Verse 51 in his speech. Consequently, he was convicted by the North Jakarta District Court and is currently punished for his fault. This case has given significant impact for mass mobilization to protest and guard 
its legal process by taking "411 movement", "212 movement", and other actions until getting the fixed legal decision (in Kracht van gewisjde). However, these ongoing actions generated a new label for some mass organizations as radicalism. As a result, the President issued government regulation instead of Regulation of Government (Perpu) Number 1/2017 about the mass organization. Unfortunately, it reaps a lot of pros and cons because it considerably betrays the freedom rights of expression, association, and assembly that has been formulated in Article 28E Paragraph 3 of the 1945 Constitution of the State of the Republic of Indonesia.

Principally, the problems are: (1) What kind of regulation is appropriate to respond to religious and intolerance conflict in Indonesia? (2) How was the purpose of issuance of regulation of government Number 1/2017 on the Mass Organization? (3) How could this regulation solve religious and intolerance conflict based on values of Pancasila? To answer these problems, the researcher argues that the law should be born from a long dialectical process between the moral values of goodness, the will of society, and the purpose of the law existence itself as a tool for governing the society. A legal pluralist approach is most needed to address these issues.

Law is required to play beyond the normative limit in order to touch the root of problems on why SARA problems arise and how to solve them. Both interdisciplinary and pluralistic approaches are needed to study the pluralistic Indonesian society in order to reunify the nation without destroying diversity and religiosity. To overcome these problems, legal pluralism approach offers a plurality-focused model for understanding the law by considering three main elements, natural law (ethic/moral/religion), positive law, and socio-legal[1].

\section{Methodology}

This study used a qualitative method to analyze the case from the moral/ethical/religion, state positivism, and socio-legal aspects. This approach was used comprehensively to see the law not only positivistic (state law) but also as a manifestation of social will (socio-legal). Then, it was associated with transcendental law with moral/ethic/ religion principles.

The data are obtained by library research that used legal materials, such as primary, secondary, and tertiary materials.

\section{Findings}

Diversity is a condition that shows the plurality of different races, religions, languages, cultures, heterogeneous, and multicultural societies. Meanwhile, religiosity is a person's way to embrace and implement his religious teachings. The Indonesian religiosity population is shown in table 1 as below:

TABLE I. POPULATION BY RELIGION

\begin{tabular}{|l|l|l|}
\hline \multirow{2}{*}{ Religion } & \multicolumn{2}{|c|}{ Percentage } \\
\cline { 2 - 3 } & $\mathbf{2 0 0 5}$ & $\mathbf{2 0 1 0}$ \\
\hline Islam & $88,58 \%$ & $87,18 \%$ \\
\hline Christian & $5,79 \%$ & $6,96 \%$ \\
\hline Catholic & $3,07 \%$ & $2,91 \%$ \\
\hline Hinduism & $1,73 \%$ & $1,69 \%$ \\
\hline Budhism & $0,61 \%$ & $0,72 \%$ \\
\hline Confusinism & $0,10 \%$ & $0,05 \%$ \\
\hline
\end{tabular}




\begin{tabular}{|l|l|l|}
\hline \multirow{2}{*}{ Religion } & \multicolumn{2}{|c|}{ Percentage } \\
\cline { 2 - 3 } & $\mathbf{2 0 0 5}$ & $\mathbf{2 0 1 0}$ \\
\hline Others & - & $0,13 \%$ \\
\hline \multicolumn{2}{|c|}{ Source Centra Bureau of Statistics Year 2010} \\
\hline
\end{tabular}

Source: Central Bureau of Statistics Year 2010

From the data above, it is shown that the majority of Indonesian people embrace Islam, while some other people embrace different religions. This diverse religiosity is particularly vulnerable to horizontal conflicts and potential for disintegration.

Based on the reports from the Ministry of Home Affairs in 2013, 2014 and Quartal 2015 (mid-January to April) data on SARA conflicts in Indonesia are listed in table 2 as below:

TABLE 2 SARA CONFLICT IN INDONESIA

\begin{tabular}{|l|ll|l|}
\hline No & Year & $\begin{array}{l}\text { Amount of } \\
\text { Conflict }\end{array}$ \\
\hline 1 & 2013 & 8 \\
\hline 2 & 2014 & 1 \\
\hline 3 & $\begin{array}{l}2015 \\
\text { April) }\end{array}$ & (MedioJanuari- & 0 \\
\hline
\end{tabular}

Source: KesbangpolKemendagri 2015

The data above explains that there was a decrease in the number of SARA conflicts in Indonesia from 2013 to 2015. These conflicts have been resolved by law and have been reconciled continuously, so that the conflicts seeds may still be minimized to grow back. In contrast, the Wahid Institute had different data for the same cases during the period 20142016, as we can see in tables 3 and 4 below:

TABLE 3 VIOLATIONS ON RELIGION AND BELIEF FREEDOM
\begin{tabular}{|l|l|}
\hline Year & Amount \\
\hline 2014 & 158 events with 187 actions \\
\hline 2015 & 190 events with 249 actions \\
\hline 2016 & 204 events with 315 actions \\
\hline
\end{tabular}
Source: Wahid Institute 2016

TABLE 4 CRIMINALIZATION AND ISSUES OF BLASPHEMY

\begin{tabular}{|l|l|}
\hline \multicolumn{1}{|c|}{ Actor } & Amount \\
\hline Conducted by state actors & 23 actions \\
\hline Conducted by non-state actors & 28 actions \\
\hline
\end{tabular}

Source: Wahid Institute 2016

The data shows that violations of religion and belief freedom tend to increase significantly from year to year. Furthermore, in 2016, a new trend of religious conflict occurred in the form of criminalization of religious scholars and desecration. How to solve this problem?

In the Republic of Indonesia, diversity and religiosity is a form of unity in diversity that has strengthened the spirit of nationhood and national unity. Indonesia is not only known as a country with a strong tolerance of diversity and religiosity but also is not easily divisible. The values of unity in diversity have been embedded since the 'archipelago' was united by the asseveration of Gajah Mada Vice Regent under the glory of Majapahit Kingdom. The 
Majapahit's glory has succeeded in uniting the archipelago because of the magical religious power centered on the King. Also, it was due to the social ties of kinship between the regional kingdoms in Java and the King in the PahomNarendra. Moreover, it also owed to the economic ties in the form of tribute offerings in the great pisowananfor local officials in Java, tax collection, and the military forces coordinated by ApatihMangkubumiGadjahMada[2].

Colonialism in Indonesia has increasingly strengthened Indonesian unity to defend the country from the invaders. The younger generations from Sabang to Merauke have pledged one motherland, one nation, and one language in the pledge of youth oath on $28^{\text {th }}$ October 1928 that was called the Youth Pledge. The values of divinity, humanity, unity, deliberation, and justice have been embedded in the soul of the Indonesian nation and institutionalized in the state of our grundnorm "Pancasila."

As we already know, Pancasila has unified Indonesian plural society. It is a meta-juristic ground norm as the highest basic norm which is full of moral, ethic, and religion. It has ideological, historical, sociological, juridical, and philosophical values. Therefore, its values do not contradict any religious values.

In other words, Pancasila is a home for pluralism so that a legal pluralism approach is mostly required to meet those problems. Indeed, both state positivism and socio-legal approaches are also needed due to the plural characteristic of Indonesian society. Tribal, regional, cultural, and religious characters are inherently embedded within the norms. These norms have formed people's behavior as well as become primordial bonds among them. Law and society have a frame called the law society framework[3].

Pancasila is staat fundamental norm with constitutive and regulative functions. According to Muladi, "Pancasila is the guiding star to examine and to give direction for positive law in Indonesia. It becomes a margin of appreciation doctrine ". Thus, the position of Pancasila is very important in the development of law, because it contains the national ideological values, namely: Historical values, i.e. birth values that are based on the history of the Indonesian nation; Sociological values, i.e. values that grow with the culture of society; Juridical values, i.e. values in accordance with laws and regulations; and Philosophical values, i.e. values that are based on a sense of justice and truth[4]. Accordingly, the Pancasila values are not in contradiction with the religious values in the Scriptures. As a legal development paradigm, Pancasila becomes guidance in the law formation in Indonesia, namely:

1. The law must protect the whole nation and guarantee national integrity, so there should be no law generating disintegration;

2. The law must ensure social justice by providing special protection for the weaker groups in order to be avoided from the exploitation of free competition against influential groups;

3. The law must be built democratically as well as democracy must be built in line with the state law;

4. The law should not only be discriminatory based on any primordial ties but also should promote religious tolerance based on humanity and civilization[5].

Thus, the law is not only a formalization of repressive rules but is also able to touch the ethical-moral side and prosperity.

The Unitary State of the Republic of Indonesia (NKRI) is a united country because of its diversity. Different tribes, languages, customs, and cultures become the unifying power of the nation. Similarly, religiosity has given a color that Indonesia is a country believing in the One Supreme, as conveyed by AriefHidayat as "a religious nation-state."

In other words, diversity and religious issues in Indonesia are parts of the complexity of prismatic and pluralistic societies. Indonesian society has characteristics that are in line with 
these dimensions. They believe in the One and only God, and their respective religions and beliefs guide them. The values of morality and ethic religion grow with their beliefs. All religions and beliefs have a mutual dialogue within the house of Pancasila. They discuss the noble values of religious teachings. All noble values in the religious teachings are convenient, and Pancasila can accommodate them in the frame of the Unitary State of the Republic of Indonesia.

Pancasila accommodates all religious people, tribes, and entire communities. It does not only guide people to maintain harmony, but also prevent them from becoming ethnocentric and only proud of their religions. In contrast, it instead suggests people emphasize the unity of the nation in the Unitary State of the Republic of Indonesia. According to Soepomo, the spirit of Indonesian nation spirituality encourages the unity of life, the unity of kawulo and gusti, i.e., unity between the outside and the inner world, between the microcosm and the macrocosm, between the people and their leaders. All human beings as a person, the human in society, other groups of society and every society in the association of life in the world are considered to have a place and duty of life (dharma) according to nature. Everything is addressed to physical and spiritual balances. The human being as a whole in society should unite and need each other. This is what so-called the integralists idea of the Indonesian nation[6]

We know that society is a group of people who have moral entity guided by their religiosity. Indeed, human beings also become part of society, and their characteristics construct them. Furthermore, society is also part of the state entity, which cannot be separated from the state's positive law. Hence, legal pluralism seeks to absorb these three dimensions in a circle of legal formalization that applies to society as individuals, part of society, and part of citizens who obey the applicable state law.

State positivism and law society should not be value-free. Also, moral, ethical, and religious values should not be released from the law. As we know that law has a direct relationship with the humans because it is deliberately created for them. Furthermore, it does not become absolute and final object, but it depends on how people see and implement it. In other words, the law is created and implemented by a man in order to regulate human life. Therefore, state positivism and law society must be guided by moral, ethic, and religion.

Law has a direct relationship with human beings, and it is inseparable from them. Principally, the law is for man, not man for the law. Law is not absolute and final, but it rather depends on how humans see and apply it. It is created and implemented by man and to govern human life. Judges, police, prosecutors, advocates, and other law enforcers are human beings. Legislative and executive legislators are also humans, as well as the societies are governed by law. Therefore, state positivism and law society should be guided by moral, ethic, and religion (natural law), as Werner Menski said about legal pluralism which is presented in chart 1 
CHART 1 LEGAL PLURALISM (Werner Menski)

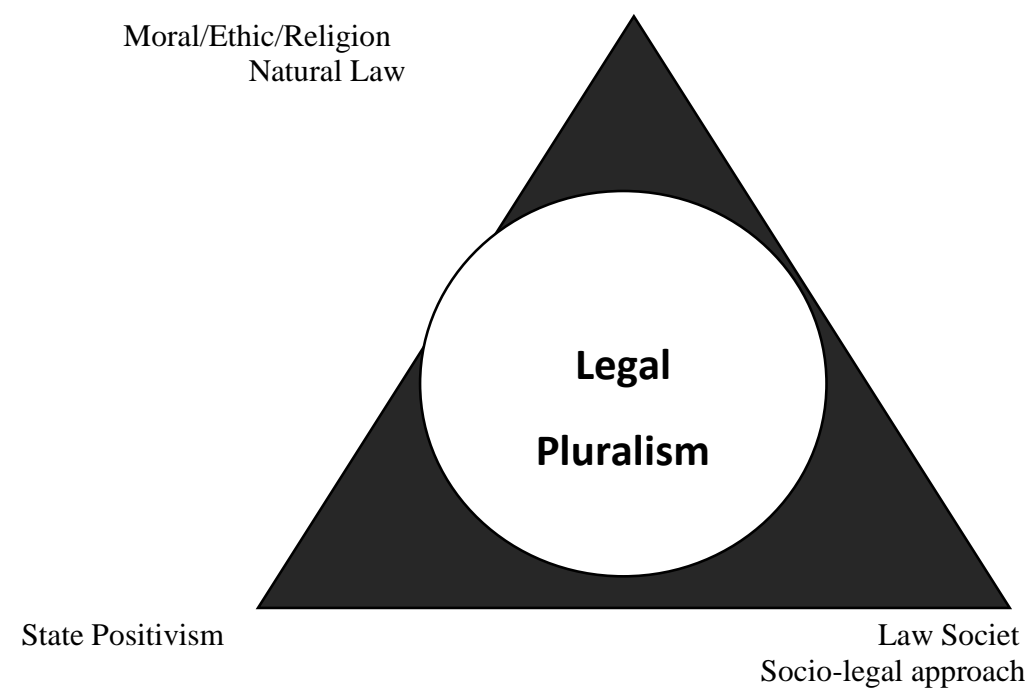

(Source: Werner Menski, 2015)

This chart explains that the law has a very many dimension and cannot be limited by space and time. It cannot only be created by considering one dimension, but also needs interdimensional linkages, namely state positivism, society, and natural law. These three dimensions would not be able to absorb the whole dimension of legal plurality in society.

We know that society is a collection of people who have moral entity guided by their religiosity. In one side, human beings become part of the society, and characteristics of their social construct them. On the other hand, they are part of the state entity that cannot be separated from the positive state law. Therefore, legal pluralism tries to absorb these three dimensions in a circle of legal formalization that applies to society as individuals, part of society as well as part of law-abiding citizens. Nevertheless, the circle of legal pluralism cannot absorb the remains of pluralism within each dimension. So, the legal pluralism should put them on each dimension as a force that cannot be ignored[7].

Also, support and participation from all elements of society are needed to solve those problems. Religious leaders, public figures, and educators should implement the moral, ethic, and ethical approaches to re-internalize the values of religion magnitude, brotherhood, and tolerance. Aspiration movements, criticisms, and opinions should be put as a balancing act in the check and balance mechanism of government policy because people are sovereigns of the state (called law society). Moreover, a nonpenal policy should be implemented through persuasive efforts by cultivating the values of unity. Still, socialization to the nationality pillars and Pancasila moral education should become a life foundation of the nation and state that must be continuously inculcated. Indeed, penal policy through law enforcement should prioritize unity as well as be done restoratively and restitutively. Furthermore, it should precede penal mediating ways, kinship, deliberation, and dialog. Hence, these ways are supposed to be taken in order to increase national unity and integrity. 


\section{Conclusion}

The plurality of societies must be understood by applying the right approach, namely, legal pluralism. The issues of diversity and religiousness can be seen and synergized from three different dimensions, namely natural law approach, law society, and state positivism. State positivism approach is made through law enforcement for humanism by penal mediation and dialog. Indeed, penal mediation by conducting a dialogue between religious and community leaders is regarded as a reconciliation effort to reunite the nation. So, religious leaders, public figures, all elements of society and state institutions might strengthen the national unity through education, religious studies, socialization and cultivation of goodness, wisdom, tolerance, national unity and integrity.

These three legal understandings in legal pluralism should be understood as integrality in a legal system. It consists of a legal structure, a legal substance, and legal culture because forming the law substance merely based on Pancasila is not enough. It must not only be followed by constructing a legal structure, but lawmakers and enforcers also must use pluralistic law. Likewise, developing a legal culture based on Pancasila must become an integral part of developing a law based on Pancasila.

\section{References}

[1] W. Menski, Comparative Law in a Global Context. Cambridge: Cambridge University Press, 2008.

[2] R. M.; U. Y. Silalahi, "Sustainable of Pancasila In Indonesian Education System: A Critical Discourse Analysis of Legal Text on Education," Res. Soc. Sci. Technol., vol. 3, no. 2, 2018.

[3] B. Z. A. Tamanaha, General Jurisprudence of Law and Society. Oxford: Oxford University Press, 2006.

[4] A. E. Kadarisman, "Local Wisdom with Universal Appeal: Dynamics of Indonesian Culture in Asian Contexts, 4th," in International Conference on Language, Society, and Culture in Asian Contexts (LSCAC), 2017.

[5] E.; I.; H. Sulistiyaningsih, "Welfare State Ideology In Indonesian Pluralism," in Proceeding The 2017 International Conference On Globalization of Law and Local Wisdom, 2017.

[6] Z. . [et. al. Salampessy, "Pancasila Paradigm: Methodology of Wawasan Nusantara of Accounting of Pancasila," Aust. Account. Bussiness Financ. J., vol. 2, no. 1, 2018.

[7] G.; S. N. Gaus, "Moral Learning In The Open Society: The Theory And Practice Of Natural Liberty," Soc. Philos. Policy, vol. 34, no. 1, pp. 79-101, 2017. 